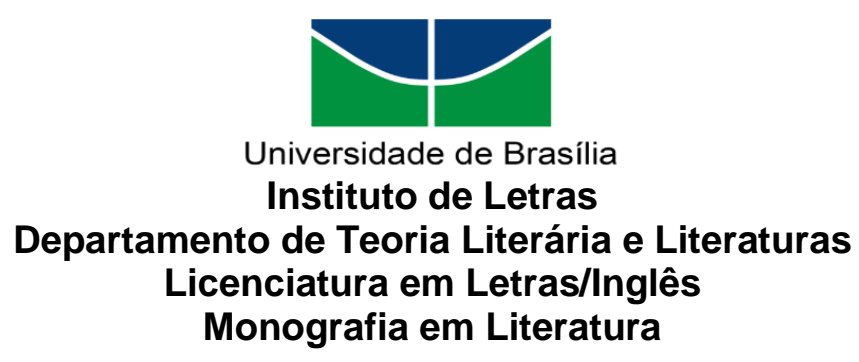

MELISSA MOTA LOPES

\title{
RELAÇÕES DE GÊNERO EM HIBISCO ROXO: O HOMEM BRANCO COMO PARADIGMA
}


ALUNA: MELISSA MOTA LOPES (13/0015431)

\title{
RELAÇÕES DE GÊNERO EM HIBISCO ROXO: O HOMEM BRANCO COMO PARADIGMA
}

\begin{abstract}
Monografia apresentada ao Departamento de Teoria Literária e Literaturas do Instituto de Letras da Universidade de Brasília como requisito parcial para obtenção do grau de bacharelado em Letras - Inglês.

Orientadora: Profa. Dra. Cintia Carla Moreira Schwantes Data da aprovação: de de 2017.
\end{abstract}

Profa. Dra. Cintia Carla Moreira Schwantes Universidade de Brasília 
À todas as mulheres que, assim como Kambili e Beatrice, perseveram todos os dias na luta contra o modelo vigente de gênero que as subjuga e oprime. 


\section{AGRADECIMENTOS}

Agradeço primeiramente à minha família, que sempre apoiou meu amor pela literatura. Um agradecimento em especial à minha irmã, Mariana, que me auxiliou nas diversas correções e reformulações deste trabalho e me deu apoio nos momentos de maior insegurança em relação a este.

Aos meus amigos, principalmente à Paula, com quem compartilhei todas as dúvidas e anseios em relação a este trabalho e à Juliana, que me ajudou na fase de revisão final.

Agradeço ao corpo docente da UnB, especialmente aos professores do departamento de Teoria Literária e Literaturas, que me inspiraram a estudar literatura.

Por fim, agradeço à minha orientadora Profa. Dra. Cintia Schwantes, pela enorme paciência e bons conselhos. 


\section{RESUMO}

Este trabalho tem como objeto de estudo o romance Hibisco Roxo, de Chimamanda Ngozi Adichie. O livro, publicado em 2003, retrata a família Achike e as formas de dominação que o patriarca, Eugene, exerce sobre esta. Tem-se por objetivo observar como se dão as dinâmicas de gênero dentro do romance a partir do paradigma de masculinidade do homem branco. Desta forma, aborda-se temas como pós colonialismo, feminilidades e masculinidades e as dinâmicas de gênero ocidental impostas na África no período colonial.

Palavras-chave: gênero, masculinidades, pós-colonialismo. 


\section{ABSTRACT}

This work is focused on the novel Purple Hibiscus, by Chimamanda Ngozi Adichie. The book, published in 2003, portrays the Achike family and the various forms of domination imposed onto them by the patriarch, Eugene. The main objective of this work is to analyze the gender dynamics in the romance from the perspective of the white man's masculinity as a paradigm for the formulation of identities in the social context of the colonial Africa. Themes such as post-colonialism, femininities, masculinities and the western gender dynamics imposed to the African Continent are touched throughout this paper.

Key words: gender, masculinities, post-colonialism. 


\section{SUMÁRIO}

INTRODUÇÃO

1. CONCEITUAÇÕES TEÓRICAS: GÊNERO E PÓS COLONIALISMO 11

1.1 Gênero

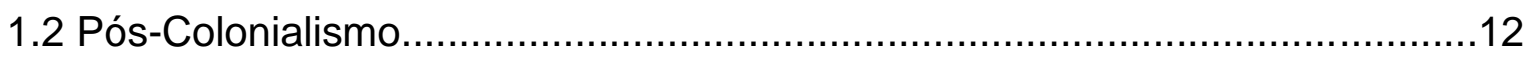

1.3 Influências do Pós Colonialismo na literatura do Continente Africano............14

1.4 Dinâmicas de Gênero na África Pós-Colonial..............................................15

2. HIBISCO ROXO: RELAÇÕES DE GÊNERO NA NIGÉRIA PÓS-COLONIAL 26

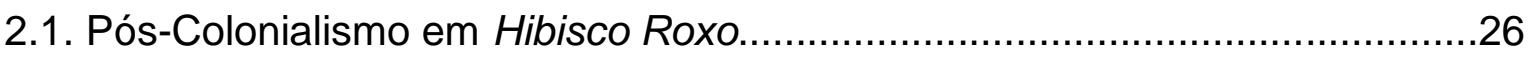

2.2. Dinâmicas de Gênero em Hibisco Roxo....................................................35

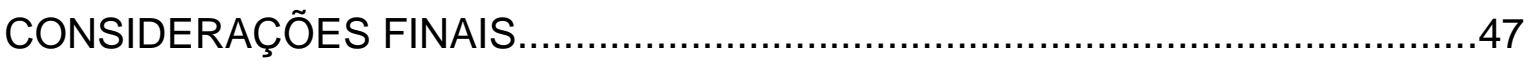

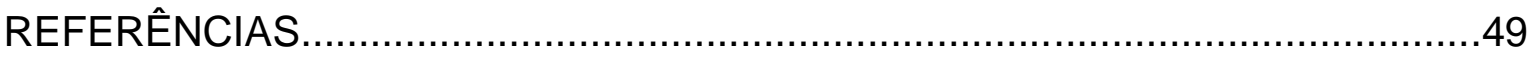




\section{INTRODUÇÃO}

Partindo do entendimento de que o gênero se estabelece relacionalmente, podemos afirmar que as definições deste estão sujeitas às relações estabelecidas com o entorno. No caso de países colonizados, como afirma Lugarinho (2017), a identidade do colonizador, que geralmente está atrelada a características como a virilidade e a violência, molda também a definição do que é masculino para a população colonizada. Em contraste com a masculinidade assim estabelecida, o feminino também se adequa, a fim de compor a contraparte desse masculino nos termos do colonizador, aonde, a partir deste modelo relacional, surgem novas dinâmicas de gênero.

A performance de gênero é portanto imposta não apenas nos termos da cultura local, mas a partir de relações em que há uma clara hierarquia. No romance Hibisco Roxo, de Chimamanda Ngozi Adichie, esse processo é explorado tanto no impacto causado em personagens masculinas quanto em femininas. Desta forma, a masculinidade como paradigma é observada através de uma dupla ótica, que afeta de forma negativa não só a sua contraparte, mas também indivíduos do sexo masculino, como Jaja, que incorpora a si valores da masculinidade ocidental a fim de se encaixar em um padrão imposto.

Da mesma forma, o personagem Eugene e a maneira com que sua masculinidade tóxica afeta a todos que o cercam é analisada. É levado em conta, para isto, o efeito da colonização não só na construção da masculinidade do personagem, mas na formulação de uma identidade que, ao agregar valores culturais da metrópole, rejeita sua cultura de origem. Observamos, a partir disto, a forma com que a tríade religião-raça-língua, proposta por Mirian do Nascimento Batista, serve como ferramenta para subjugar e impor a cultura ocidental aos povos africanos colonizados.

A família Achike, que por sua vez é percebida como um microcosmos da sociedade em que está inserida, é retratada de forma a expor a disjunção entre a identidade privada e a pública do patriarca Eugene. O personagem, que apesar de atuar como membro relevante de sua comunidade e igreja e mostrar-se caridoso e solidário para estes, revela-se, no ambiente doméstico, extremamente autoritário, e 
violento, podando a liberdade de seus familiares e impondo suas crenças e convicções a eles, que, passivos e silenciados, se curvam às vontades do homem.

A violência doméstica, conforme retratada no romance de Adichie, enquanto vitima mulheres e crianças, trabalha para estabelecer a autoridade masculina e funciona, portanto, como um dado de identidade. Ela perpetua um estereótipo da masculinidade ocidental radicado na cultura local, que se mistura aos traços constitutivos da masculinidade desde um padrão colonizador. A partir disso, é analisada, então, a forma com que a masculinidade de Eugene atua no nível doméstico, moldando Kambili e Beatrice e fazendo-as, desta forma, personagens vazias de uma essência pessoal, tornando-se meras extensões das vontades dele.

O primeiro impacto da violência de Eugene para com sua família é o silenciamento das vozes das personagens, que só se comunicam de forma monossilábica ou através de olhares. A situação, no entanto, muda a partir do relacionamento de Beatrice, Jaja e Kambili com Ifeoma, que apesar de ser irmã de Eugene, serve de contraponto às visões dogmáticas e engessadas deste. A mudança, que se dá de forma gradual para todos, porém ainda mais lenta para Kambili e Beatrice que para Jaja, conduz a um desfecho que, refletindo a essência violenta de Eugene, mostrou-se desde o início inevitável: o assassinato deste para a que a liberdade de sua família se pudesse fazer completa.

Apesar disto, no entanto, as amarras das masculinidades impostas ainda aprisionam Jaja, que preso ao pressuposto de que, com a morte do pai deve assumir o posto de "homem da casa", responsabiliza-se pelo assassinato de Eugene e vai para a cadeia no lugar de sua mãe. É inaugurada, assim, para a família Achike, uma nova fase, em que apesar de libertos da presença tirânica do patriarca, ainda há dor e silêncio. A partir disso, é perceptível como as masculinidades são recicladas e renovadas a cada geração, passando de pai para filho e, da mesma forma, remoldando a identidade da mulher. Com base nisso, são percebidas, no romance, a importância da sororidade e da resistência feminina na libertação destas mulheres submissas.

A análise do romance, partindo dos pontos esclarecidos anteriormente, se dá, então, em duas fases. A primeira, dedicada às clarificações quanto aos temas 
abordados, tem como objetivo aprofundar o conceito de gênero como uma construção social a partir da afirmação de Simone de Beauvoir de que "não se nasce mulher, torna-se". São esclarecidos também o conceito de pós colonialismo e da forma com que este afeta a literatura e as relações de gênero de acordo com Thomas Bonnici, Ogaga Okuyade, Bill Ashcroft et al, Maureen Amaka Azuike, Mário César Lugarinho e Roberta Mara Resende, dentre outros. A segunda fase consiste na análise de Hibisco Roxo a partir dos conceitos estabelecidos na primeira etapa, passando por temas como o pós colonialismo e a forma com que este afeta as relações de gênero dentro do contexto do livro. 


\title{
CAPÍTULO 1
}

\section{CONCEITUAÇÃO TEÓRICA: GÊNERO E PÓS-COLONIALISMO}

\subsection{Gênero}

A palavra gênero se originou do termo grego genus, que significa "tipo", "raça". No século XV, o termo passou a ser associado com o sexo biológico de um indivíduo, passando a ser entendido, então, como um sinônimo do termo "sexo". Desta forma, tanto a palavra "sexo" quanto a palavra "gênero" passaram a ser usadas como forma de categorizar os seres a partir de seus órgãos sexuais, sendo "o gênero feminino" designado para as fêmeas e, por conseguinte, "o gênero masculino" sendo sinônimo do que era biologicamente definido como macho.

Foi em 1949, a partir da publicação de "O Segundo Sexo", de Simone de Beauvoir, que marcou o início da chamada Segunda Onda do Feminismo, que o uso do termo começou a se transformar.

\begin{abstract}
"Não acredito que existam qualidades, valores, modos de vida especificamente femininos: seria admitir a existência de uma natureza feminina, quer dizer, aderir a um mito inventado pelos homens para prender as mulheres na sua condição de oprimidas. Não se trata para a mulher de se afirmar como mulher, mas de tornarem-se seres humanos na sua integridade." (BEAUVOIR, Simone de. O Segundo Sexo Vol 2: A Experiência vivida, 1967.)
\end{abstract}

A partir do livro de Beauvoir, portanto, o uso do termo "gênero" começou a ser questionado, passando a ser diferenciado de sexo; sendo sexo a classificação dos seres como macho e fêmea de acordo com seu órgão sexual, e gênero passando a ser usado em escritos feministas, a partir de 1970, como o conjunto de características socialmente convencionadas como naturais de cada sexo. Desta forma, o gênero passou a ser o termo designado para falar do que era esperado de homens e mulheres nas esferas comportamental e psicológica a partir da diferenciação sexual, e de como isso foi historicamente usado como ferramenta que define relações sociais desiguais de poder entre os sexos dentro de uma sociedade. Apesar de ainda hoje a definição de gênero ser muito comumente confundida com sexo, de acordo com o dicionário online Merrian-Webster, gênero se refere aos 
"traços comportamentais, culturais ou psicológicos tipicamente associados a um sexo".

A partir do conceito de gênero e da ideia de que este é uma performance, ou um construto social, e da afirmação de Simone de Beauvoir de que "não se nasce mulher, torna-se mulher", foram elaboradas teorias a respeito das chamadas "masculinidades" e "feminilidades", que seriam o conjunto de atributos, condutas e comportamentos convencionados como particulares de cada um dos sexos. Desta forma, características como sensibilidade, delicadeza e gentileza, que são comumente associadas ao sexo feminino, são consideradas indesejáveis quando percebidas em indivíduos do sexo masculino, bem como características percebidas como inerentemente masculinas, como comportamento violento, a assertividade e a razão em detrimento da emoção (sendo a emoção mais ligada ao sexo feminino), são reprimidas quando encontradas em mulheres. De acordo com a historiadora Joan Scott, o gênero deve ser pensado de forma relacional, ou seja, masculinidades e feminilidades são conceitos intrínsecos e interdependentes que são moldados um em função do outro. Desta forma, Scott defende que, historicamente, as duas categorias foram construídas a partir de uma ótica assimétrica, em que é atribuída ao homem uma posição social de maior poder e de dominação em relação à mulher.

O pensamento feminista da terceira onda vai assimilar, em sua reflexão teórica, os impactos de contexto histórico, classe social, raça e orientação sexual sobre sujeitos identificados, socialmente, com o gênero feminino.

\subsection{Pós-Colonialismo}

O pós-colonialismo é uma corrente de pensamentos e teorias que tem por objetivo analisar os efeitos da colonização em países colonizados. No que tange à teoria literária, as correntes pós-colonialistas lidam com a literatura de países que outrora foram colônias de potencias europeias como Inglaterra, Portugal, França e Espanha. A literatura pós colonial, sendo assim, é fruto das tensões sociais provenientes tanto do processo de colonização quanto do de descolonização. A teoria pós colonial passou a ocupar um lugar de relevo no corpo teórico que se debruça sobre a pós modernidade em 1970, tendo como obra fundadora o livro 
Orientalism, de Edward Said, e conduzindo à produção de um importante corpo de textos sobre as relações pós coloniais, dentre as quais podemos destacar a obra de Bill Ashcroft e Thomas Bonnici.

De acordo com Bill Ashcroft et al (2002), a literatura do povo colonizado passa por três fases distintas. Na primeira fase, os escritos, que são produzidos principalmente pelo colonizador, tem caráter descritivo, porém livre de objetividade, visto que apresentava, por vezes, caráter xenofóbico, exagerando em críticas negativas aos nativos das colônias com o objetivo de exaltar as características das metrópoles em detrimento da nação subalterna. Tal visão preconceituosa afetou profundamente a forma com que o continente Africano passou a ser entendido pelo mundo ocidental, como ressalta Chimamanda Ngozi Adichie em sua palestra The Danger of a Single Story, para o TED:

This single story of Africa ultimately comes, I think, from Western literature. Now, here is a quote from the writing of a London merchant called John Locke, who sailed to West Africa in 1561, and kept a fascinating account of his voyage. After referring to the black Africans as "beasts who have no houses," he writes, "They are also people without heads, having their mouth and eyes in their breasts." Now, I've laughed every time l've read this. And one must admire the imagination of John Locke. But what is important about his writing is that it represents the beginning of a tradition of telling African stories in the West. A tradition of Sub-Saharan Africa as a place of negatives, of difference, of darkness, of people who, in the words of the wonderful poet, Rudyard Kipling, are 'half devil, half child'. (ADICHIE, Chimamanda Ngozi. The Danger of a Single Story, 2009.) ${ }^{1}$

Na segunda fase, a literatura local começa a ser produzida pelo colonizado, mas passa por um processo de censura pela metrópole, e por isso ainda não tem nenhum caráter identitário nacional, apresentando um viés ideológico compatível ao do colonizador e distanciado da realidade da colônia. O terceiro momento desta literatura, no entanto, por ocorrer após o processo de independência, assume um caráter nacionalista e de profundas críticas e questionamentos à metrópole, por esta

\footnotetext{
1 Essa história única da África vem, eu acho, da literatura ocidental. Agora, uma citação de um mercador londrino chamado John Locke, que viajou para o oeste da África em 1561, e produziu uma fascinante narrativa de sua viagem. Após se referir aos negros africanos como "bestas que não tem casas", escreveu, "São também pessoas sem cabeça, que tem a boca e os olhos localizados no peito.". Eu rio todas as vezes que leio isso. A imaginação de John Locke é admirável. Mas, a parte mais importante deste escrito é que ele representa o início da tradição de contar histórias sobre a África no Ocidente. Um tradição que retrata a África Subsaariana como um lugar de negativos, de diferença, de escuridão, de pessoas que, segundo as palavras do maravilhoso poeta, Rudyard Kipling, são 'meio demônio, meio criança'. (Tradução livre)
} 
ser a primeira fase em que a literatura local é produzida inteiramente pelo colonizado, sem que haja intervenção alguma por parte da metrópole. É esta a fase que caracteriza a literatura pós colonial:

A characteristic of dominated literatures is an inevitable tendency towards subversion, and a study of the subversive strategies employed by post-colonial writers would reveal both the configurations of domination and the imaginative and creative responses to this condition. (ASHCROFT, Bill et al. The Empire Writes Back, Theory and Practice in Post-Colonial Literatures, 2002) ${ }^{2}$

Thomas Bonnici, em seu texto Pós-colonialismo e Representação Feminina na Literatura Pós-Colonial em Inglês, fala sobre como a figura feminina é representada na literatura e em como essa representação é profundamente afetada pelo imperialismo e pela globalização. Para ele, a opressão da mulher é produzida através da estrutura de classe e serve de óleo para as engrenagens do capitalismo; a opressão sofrida pela mulher, como consequência, varia de acordo com a classe social. Para o autor, ainda, enquanto as atividades femininas sofrerem interferências do patriarcalismo e do colonialismo, não haverá igualdade; assim, ele diz que o sucesso do feminismo é ambíguo por ainda não ser completo, mas que já gera melhoras quanto à tolerância e a luta contra o imperialismo e a dominação. Bonnici defende com otimismo o futuro da literatura de autoria feminina, que contará histórias e experiências verdadeiras e dará voz às mulheres ainda tão marginalizadas na atualidade, especialmente em países, como é o caso da Nigéria, aonde são vividas as consequências patriarcais do colonialismo e do imperialismo.

\subsection{Influências do Pós Colonialismo na Literatura do Continente Africano}

Quando se fala de literatura pós colonial, é necessário destacar a importância das produções literárias do continente africano. Após o processo de independência, que se deu entre os anos 1960 e 1970, surgiu no continente, como reflexo da necessidade de reconstruir os países e culturas locais, uma literatura de caráter majoritariamente nacionalista, que tinha como característica forte uma visão positivista acerca das culturas e costumes africanos. Já reestabelecida a identidade

\footnotetext{
2 Uma característica da literatura do dominado é uma tendência inevitável à subversão, e um estudo das estratégias subversivas empregadas por escritores pós coloniais revelaria ambas as configurações de dominação, e as respostas imaginativas e criativas a essa condição. (Tradução livre)
} 
nacional, surgiu um segundo momento na literatura pós colonial africana, que se desenvolveu de acordo com o modelo de evolução da literatura da colônia proposto por Ashcroft et al (2002), aonde o interesse dos autores passou a ser não o processo de recuperação de suas nações, mas a forma com que se deu essa recuperação, debatendo o processo de reconstrução identitária do país, discutindo sua pluralidade e botando em cheque as disparidades destes países. Para Ogaga Okuyade (2009), a literatura africana pós colonial oscila entre estes dois momentos, que ele chama de colonialismo e pós colonialismo, e continuará assim indefinidamente, pois

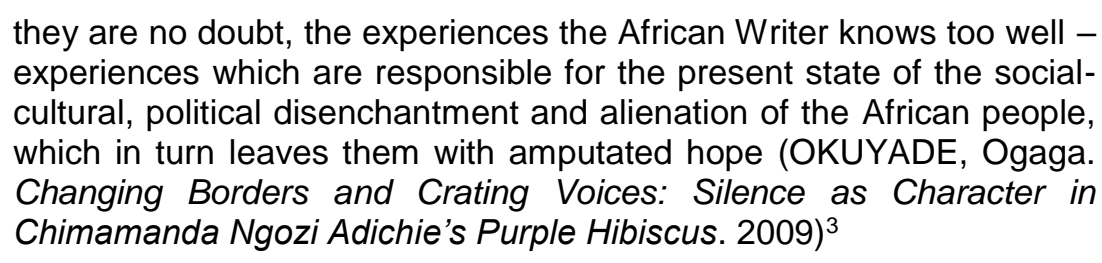

De acordo com Okuyade, ainda, a autora nigeriana Chimamanda Ngozi Adichie transita em sua obra e, mais especificamente, em seu livro Hibisco Roxo, entre esses dois temas, discutindo assuntos como a herança colonial, a guerra civil e a condição da mulher na Nigéria contemporânea. Ressalto, a partir dos temas usados por Adichie em seu romance, a discussão das dinâmicas de gênero e poder e a construção de masculinidades e feminilidades a partir dos modelos sociais impostos pelo colonizador na Nigéria.

\subsection{Dinâmicas de gênero na África pós colonial}

Em sua dissertação de mestrado Gênero e Nação na Fiç̧ão de Chimamanda Ngozi Adichie, Roberta Mara Resende fala sobre as dinâmicas de gênero na África pré-colonial e discute a influência dos ideais ocidentais na expressão de gênero no continente. Tendo como base o texto Male Daughters, Female Husbands (1988), da antropóloga Ifi Amadiume, Resende esclarece o sistema de gênero da etnia

\footnotetext{
${ }^{3}$ Estas são sem dúvidas experiências que o Escritor Africano conhece muito bem - experiências que são responsáveis pelo presente estado de alienação e desencantamento sociocultural e político do povo africano, que em retorno tolhe suas esperanças. (Tradução livre)
} 
nigeriana Igbo $^{4}$, que vivia, no período pré-colonial, um sistema sexo/gênero diferente do modelo ocidental do que é feminino e masculino. De acordo com o texto,

\begin{abstract}
Na África, gênero se refere não só ao dado biológico que funda um sistema cultural de representação e comportamento como também ao papel social ativo desempenhado pelo indivíduo. Nesse sentido, destaca-se a flexibilidade das relações de gênero, observada, por exemplo, na possibilidade de a mulher se tornar "esposa de outra mulher. (RESENDE, Roberta Mara. Gênero e Nação na Ficção de Chimamanda Ngozi Adichie. 2013, p.25)
\end{abstract}

A autora ressalta, ainda, que essa diversidade também está presente no idioma falado pelo povo Igbo, no qual, assim como na língua inglesa, além dos pronomes masculino e feminino, há uma partícula neutra. Além disso, ela destaca que, no passado pré-colonial, mulheres poderiam ser classificadas como "masculinas" ou "femininas", podendo, a partir de sua classificação como "masculinas", desposar outras mulheres mediante pagamento de dote. Apesar de não poderem se casar oficialmente, as mulheres que assumiam a função de "marido" podiam ter filhos, sendo estes gerados por suas esposas ou por elas mesmas com outros homens. Vale ressaltar, no entanto, que apesar desta mobilidade de gênero e da influência da mulher na sociedade e na economia nigerianas, Resende ainda menciona em seu texto que a posse de terra era privilégio reservado apenas aos homens, enquanto trabalhos domésticos, como a preparação de alimentos, eram restritos às mulheres. Assim, a autora mostra que, de forma semelhante ao sistema ocidental de gênero, podia ser observada na Nigéria pré-colonial a designação de papéis de gênero seguindo um ideal "basicamente heterossexual que privilegiava o sexo masculino, mas dentro do qual a mulher não deixava de possuir meios de defender seus direitos e impor suas decisões." (RESENDE, 2013).

Resende diz que, apesar de não exercerem influência nas decisões políticas de suas comunidades, as mulheres Igbo não eram marginalizadas e utilizavam de diversos subterfúgios para obter controle de suas vidas e alcançar certa independência em sua sociedade. Segundo a autora, a força destas mulheres se dava, principalmente, através de organizações como a Associação das Mulheres, a

\footnotetext{
4 Embora no romance de Adichie a grafia utilizada seja "igbo", nas bibliografias utilizadas neste trabalho a palavra também foi encontrada grafada como "ibo". Embora ambos os termos sejam usados, escolhi utilizar "igbo" a fim de manter alinhamento com a obra literária base do trabalho.
} 
Associação das Filhas e a Associação das Viúvas, através das quais elas "se faziam ouvir e exerciam forte influência política" (RESENDE, 2013):

Era através de organizações dessa natureza que as mulheres alcançavam poder no patriarcado que era moldado para marginalizalas. É notável observar que os homens ibo não tinham o mesmo tipo de rede de associações e de solidariedade sexual que permitia às mulheres mobilizar-se para além das fronteiras num corpo unido. (EZEIGBO, Theodora Akachi. Traditional Women's Institutions in Igbo Society, 1990. p. 150 apud. RESENDE, Roberta Mara. Gênero e Nação na Fiç̧ão de Chimamanda Ngozi Adichie. 2013, p.26)

Além dessas associações, a autora também relata que as mulheres igbo pareciam utilizar de greves como meio de exercer poder dentro da comunidade, privando os homens de sexo e negando-se a cozinhar:

$\mathrm{Na}$ pior das hipóteses, se os homens de uma linhagem fossem teimosos, as esposas faziam greve, e nesse caso se recusariam a cozinhar ou ter relações sexuais com seus maridos. Nessa cultura, os homens não cozinhavam: o controle da alimentação era, portanto, um trunfo político para as mulheres. Na sexualidade também, as realidades de gênero eram tais que se acreditava que as fêmeas prestavam serviços sexuais; daí o uso político da ameaça de suspensão coletiva dos serviços sexuais por parte das mulheres. (AMADIUME, Ifi. Male Daughters, Female Husbands: Gender and Sex in African Society, 1998, p.85, apud RESENDE, Roberta Mara. Gênero e Nação na Fiç̧ão de Chimamanda Ngozi Adichie. 2013, p.27)

Além disso, a mulher também era responsável pela agricultura, e a elas eram destinadas, após o casamento, a posse de terras para que pudessem alimentar a família, visto que essa tarefa era, de acordo com a cultura, reservada apenas às mulheres. Ou seja, as mulheres tinham como obrigações após o casamento os trabalhos de processar, preservar, armazenar e comercializar o alimento. Como consequência disso, Resende ressalta, as mulheres poderiam adquirir um elevado status econômico, em especial aquelas que conseguiam, através dessas atividades, enriquecer e adquirir propriedades, obtendo títulos e podendo adquirir prestígio e influência maiores que os masculinos.

Outro subterfúgio encontrado pelas mulheres igbo para exercer poder era, de acordo com Resende, através da instituição chamada de Nluikwa, que permitiam que as mulheres gerassem filhos que herdariam as terras de seus pais, tendo o poder, enquanto seus filhos não crescessem, de administrar os negócios de seus genitores; essas mulheres eram conhecidas como "filhas-macho", pois, apesar de 
serem mulheres, estavam em local de poder caracteristicamente masculino. A algumas, da mesma forma, era permitida a instituição do "casamento de mulheres", em que uma mulher poderia casar-se com outras, que passariam então a dever à sua esposa fidelidade e a prestação de serviços socialmente destinados à mulher, como a preparação de alimentos e a agricultura. De acordo com Resende, que aqui cita Izeigbo, "esta instituição permitia à mulher adquirir maior prestígio social. Invariavelmente, apenas as mulheres ricas, dotadas de personalidades fortes e influência poderiam exercer tal poder." (EZEIGBO, 1990, p.152-153 apud RESENDE, 2013, p.27).

Outra instituição através da qual a mulher poderia adquirir benefícios sociais citada por Resende é a Iko Mbara, através da qual o marido, que geralmente era um homem mais velho e por vezes infértil, oferecia serviços sexuais da esposa a outro homem regularmente em troca de duas jarras de vinho, carne, galinha, dinheiro e ajuda na lavoura quando necessário. Resende destaca que tal arranjo, apesar de objetificar a mulher e trata-la como moeda de troca, também representava certo benefício para as esposas, visto que elas tinham o direito de escolher o homem com que se relacionariam, podendo obter prazer destas relações. Outro benefício era, para Resende, que destes relacionamentos as mulheres poderiam gerar filhos e, desta forma, usufruir do direito de herança de seu marido estéril.

Apesar de usufruírem da possibilidade de reinvindicação de direitos e da mudança de vida, Resende destaca que a mulher não ocupava um lugar de simetria em relação ao homem. Segundo a autora, temas como a sexualidade feminina e a menstruação eram tabu entre o povo igbo, e desvios da norma como o sexo ou a gravidez fora do casamento geravam a exclusão social da mulher e eram motivo de vergonha para suas famílias. De acordo com a autora, ainda, apesar de não haver registro de termos para definir um homem como um mau marido mesmo que esse não cumprisse o que era socialmente designado como seu dever, uma mulher era considerada uma esposa ruim quando, por algum motivo, não alimentasse bem o marido ou deixasse de cumprir suas obrigações como esposa e mãe.

Dessa forma pode-se concluir, através das afirmações de Resende sobre as formas através das quais as mulheres igbo se impunham na comunidade, que apesar de estas possuírem oportunidades de transitarem socialmente e ocupar 
posições de poder na sociedade, as mulheres ainda ocupavam, assim como no ocidente, uma posição de subalternidade. Para a autora, portanto, a mulher igbo, apesar de forte e socialmente ativa, aceitava a subordinação ao homem e ao casamento como forma de ascender socialmente:

A principal divindade em Nnobi é uma deusa chamada Idemili. As narrativas sobre Nnobi dão conta de uma mulher poderosa, mas que desejou casar-se e ser domesticada. Assim, pode-se entender melhor por que a mulher ibo é ativa socialmente, mas aceita a subordinação no casamento, o que pode ser entendido e justificado por meio da religião. É interessante observar que as representações das deusas, em madeira, projetam a mulher em tamanho maior do que seu esposo. Mas, apesar de mais poderosa, ela ainda é dependente. (RESENDE, Roberta Mara. Gênero e Nação na Fiç̧ão de Chimamanda Ngozi Adichie, 2013.)

Apesar disso, é ressaltado por Resende e por Maureen Amaka, também, que as mulheres nigerianas eram conhecidas por seu forte ativismo e por sua presença forte na construção da história do país. De acordo com Amaka em Women's Struggles and Independence in Adichie's Purple Hibiscus and Half of a Yellow Sun (2009),

\begin{abstract}
Historically, women are not new to the history of struggles in Nigeria. Well documented in Nigerian History are the enigmatic Amazons who fought tirelessly, alongside the men, in the 1950's and 1960's for Nigeria's independence. Mrs Margaret Ekpo, Mrs Funmilayo Ransome-Kuti, Lady Yinka Abayomi, Hajiya Sawaba Gambo and Chief Mrs Janet Mokelu were among the fearless women who struggled relentlessly to re-shape the Nigerian history." (AZUIKE, Maureen Amaka. Women's Struggles and Independence in Adichie's Purple Hibiscus and Half of a Yellow Sun. 2009. $)^{5}$
\end{abstract}

Tanto para Amaka quanto para Resende, é fato que o colonizador europeu impôs as amarras de gênero ocidentais no continente africano de forma a suprimir o conceito de gênero mais flexível do povo Igbo, diminuindo a importância e a influência da mulher na sociedade nigeriana. Amaka ressalta ainda que, seguindo os valores patriarcais da cultura ocidental, o colonizador, ao estabelecer a educação formal no continente, decidiu que os homens teriam acesso à educação, enquanto a mulher ficaria reclusa ao ambiente doméstico e se dedicaria a atividades como

\footnotetext{
5 Historicamente, as mulheres não são alheias aos percalços históricos da Nigéria. São bem documentadas na história do país as enigmáticas Amazonas, que lutaram incansavelmente ao lado dos homens, entre 1950 e 1960, pela independência da Nigéria. Sra. Margaret Ekpo, sra. Funmilayo Ransome-Kuti, Lady YinkaAbayomi, Hajiyia Sawaba Gambo e Chefe sra. Janet Mokelu estavam entre as destemidas mulheres que batalharam implacavelmente a fim de remoldar a história nigeriana. (Tradução livre)
} 
limpar, cozinhar e costurar, gerando a primeira grande diferenciação entre os sexos, diferenças essas que permanecem até hoje enraizadas no senso comum não só do continente africano, mas de todo o mundo. Para a autora, isso fez com que a mulher passasse a ser vista como um cidadão de segunda classe e de menor importância no contexto social.

De acordo com Diego Santos Vieira de Jesus, em Bravos Novos Mundos: uma leitura pós-colonialista sobre masculinidades ocidentais (2011), a produção intelectual dos imperialistas dos séculos $\mathrm{XVI}$ e XVII e as consequentes práticas políticas do período "apontavam para um processo de preservação e de cristalização da integridade do 'império da uniformidade' nos principais estados nacionais modernos em formação na Europa naquele contexto" (VIEIRA DE JESUS, 2011), assim, toda diferença era vista como ameaça, sendo tudo que era divergente mantido no exterior através da defesa de fronteiras, e a diferença doméstica combatida através do que o autor chama de "a cruzada interna". Nesse contexto, a masculinidade do colonizador, que era associada à bravura na conquista de terras e à força usada na imposição de sua cultura a outros povos, servia como mecanismo de dominação político-cultural tanto dos povos que eram subjugados pelo colonizador europeu quanto da mulher, cuja sexualidade era controlada pelo Estado e pela Igreja, o que gerou as condições necessárias para o fortalecimento do domínio masculino em todas as esferas sociais, particularmente, segundo o autor, "no que dizia respeito ao direcionamento moral e religioso entre homens e mulheres e à associação dessas normas sociais com as assimetrias sociopolíticas em múltiplas áreas" (VIEIRA DE JESUS, 2011).

Para o autor, a combinação desta masculinidade dominante do colonizador com ideias etnocêntricas de superioridade e hierarquização social conduziu a novos sistemas de identificação, levando o colonizador a entender os nativos recémdescobertos como um povo que era dotado de potencial, porém sem qualquer cultura ou com uma "falsa cultura", que é assim denominada pelo autor por ser vista pelo colonizador como deturpada; sendo assim, esses povos eram vistos como receptáculo para uma "cultura certa", a cultura ocidental. Apesar dessas diferenças, de acordo com Vieira de Jesus, os colonizadores sentiam desejo pela mulher colonizada, desejo este que fazia com que o colonizador expressasse insegurança e um certo temor em relação às diferenças étnico-culturais, visto que as possíveis 
relações sexuais que eram mantidas com essas mulheres e a possível geração de filhos advindas destas, eram vistas como potenciais desestabilizadores da cultura dominante do colonizador, gerando um sentimento de dualidade em relação às mulheres, que passaram a ser enxergadas a partir de duas óticas distintas, ora sendo objeto de desejo, ora uma ameaça às estruturas de poder colonial e à noção masculinizada europeias de dominação política.

Ainda de acordo com Vieira de Jesus, o que pauta as relações entre colonizador e colonizado até o fim do século XIX é a ambiguidade de sentimentos expressa ora pelo desejo, ora pelo medo. Para ele, a caracterização do não-europeu como "selvagem" se deu pela necessidade do colonizador de, de alguma forma, entender a diferença, o que os levou a classifica-la como uma inferioridade; inferioridade esta que buscavam objetificar e disciplinar, visando preservar sua identidade e superioridade. Assim, a dominação europeia, que era sustentada pelo ideal de masculinidade, era pautada pela insegurança e pelo desejo. Para o autor, essa dualidade de sentimentos é trazida à tona através da ficção, aonde "as inclinações masculinas dos textos acerca da intervenção europeia na Ásia e na África são permeadas por homoerotismo e a concepção ameaçadora da mulher" (VIEIRA DE JESUS, 2011).

Para Resende, como resultado de as escolas da colônia serem administradas por líderes religiosos, escola e igreja eram entendidos como sinônimos. Valores religiosos passaram a ser, desta forma, ensinados na escola; valores que, é claro, se resumiam ao que o colonizador considerava pertinente, culminando na repreensão dos costumes, crenças e da religião local, e implantando os valores religiosos ocidentais. Além de inserir valores da metrópole nessas culturas, o aparato colonial foi responsável por propagar a ideia de que a cultura africana e tudo o que advinha dela era errado e deveria ser extinto, e isso foi usado como ferramenta para extinguir a cultura do colonizado, substituir o dialeto local pelo idioma da metrópole e ocidentalizar até mesmo as mais básicas expressões culturais, como a escolha de nomes, visto que, assim que as crianças ingressavam nas escolas, eram forçadas a abandonar seus nomes de raiz africana, sendo rebatizadas com nomes tipicamente ingleses que geralmente referenciavam à religiões cristãs, como Michael ou Grace. Desta forma, o Cristianismo baniu a deusa local e substituiu-a pelo culto ao seu deus, interditando, como consequência, as 
tradições da cultura local, como a poligamia e os "maridos-fêmea". Da mesma forma, as instituições que davam poder social às mulheres foram extintas, fazendo com que estas fossem inseridas na vida paroquial, de forma que "A mulher passou a integrar o corpo da igreja, enquanto o homem se tornou cabeça da instituição." (RESENDE, 2013. p.31).

\begin{abstract}
Os missionários trouxeram para a África a ideia de que o lugar da mulher é a casa, utilizando lugares-comuns como os que davam conta de que a mulher não entende matérias eminentemente "masculinas", como ciências, política e negócios. Assim, a representação da mulher sofre modificações durante o colonialismo, passando de produtora da subsistência a indivíduo subalterno na teia social. O homem não foi totalmente excluído da estrutura de poder colonial. Alguns líderes locais, que antes se destacavam por seus feitos, são chamados a fazer parte de uma instituição chamada "Nwo", da qual as mulheres são excluídas. Se antes tinham poder de fala na "Umuna", elas agora apenas limpam o espaço das reuniões. (RESENDE, Roberta Mara. Gênero e Nação na Fiç̧ão de Chimamanda Ngozi Adichie, 2013.)
\end{abstract}

Assim, a mulher passou a ser restrita ao espaço doméstico, enquanto o homem era preparado para dar conta de serviços administrativos.

Da mesma forma que a chegada do colonizador reformulou o papel da mulher na sociedade africana, os papeis do homem, e consequentemente os conceitos de masculinidade e as relações de gênero, foram remoldadas. $O$ homem africano teve seus ideais de masculinidade remodelados a partir das masculinidades ocidentais observadas no comportamento do colonizador. Assim, a partir da masculinidade do homem branco, que era "associada à bravura na conquista de terras fora do continente europeu e à força na imposição de sistemas político-sociais europeus aos nativos" (JESUS, Diego Santos Vieira de, 2011, p. 129), foram definidos novos conceitos de masculinidades e de como deveria se portar, social, comportamental e psicologicamente, o homem africano, criando na África o ideal ocidental de homem que tem como dever performar o papel social de "homem da casa", sendo responsável por "controlar" sua esposa e filhos e tendo o dever de sustentar o lar. $\mathrm{Na}$ esfera psicológica, passou a ser esperado destes homens um comportamento caricato de masculinidade, que por vezes é violento, dá preferência à razão em detrimento da emoção e que evita características tidas como tipicamente femininas, como a flexibilidade e a compreensão. 
Para Mário César Lugarinho em Paradigmas Confrontados: Algumas Masculinidades nas Literaturas Africanas de Língua Portuguesa (2017), a partir de estudos antropológicos, é perceptível que o conceito de masculinidades não é fixo, e sim moldado de acordo com o contexto político, histórico e geográfico em que o indivíduo está inserido. Por esse motivo, para ele, a identidade masculina foi profundamente alterada com o estabelecimento do capitalismo, mudança que pode ser observada através da análise de personagens clássicos da literatura mundial, como Werther e Brás Cubas, que trazem uma mutação na representação da identidade masculina; ao contrário desses personagens, no entanto,

Heróis diversos, inseridos numa perspectiva colonial, e/ou estritamente nacional, especialmente nas obras de Jonathan Swift e de Joseph Conrad, ou, mesmo, o Fradique Mendes, demonstravam as (novas) virtudes necessárias à constituição de uma identidade masculina para o mundo moderno. O aventureiro, personagem característico dessa escrita, representa o homem europeu, cujo empreendedorismo colonial o redimia da instabilidade da vida urbana e moderna. (LUGARINHO, Mário César. Paradigmas Confrontados: Algumas Masculinidades nas Literaturas Africanas de Língua Portuguesa, 2017, p.142)

Para o autor, a submissão ao homem branco europeu, imposta ao homem negro através da colonização, resultou na reconstituição da identidade deste a partir da identidade do colonizador. Assim, em locais como a África Subsaariana, em que eram características "a autonomia feminina e largos arranjos familiares" (LUGARINHO, 2017), a aglutinação da identidade do homem branco europeu resultou no esfacelamento deste tipo de núcleo familiar, dando origem a famílias nucleares em que o homem passou a ser o "chefe". Lugarinho diz, no entanto, que a posição deste homem passou a ser polarizada, visto que, enquanto era protagonista em sua família, nas relações sociais ainda ocupava uma posição inferior por conta de sua origem étnica, racial e geográfica em relação ao homem branco, que ocupava um lugar de maior poder dentro do contexto colonial em que ambos estavam inseridos. Assim, de acordo com Lugarinho, a identidade do homem branco, independentemente de sua posição política ou social, pautava as relações destes com os outros indivíduos de uma sociedade colonial, aonde as identidades destes eram moldadas em função da identidade do homem branco. Desta forma, mulheres e crianças, independentemente de raça ou classe social, e homens mestiços ou negros eram hierarquizados socialmente de modo que, quanto mais se 
afastam do modelo ideal do homem branco europeu, mais marginalizados se tornavam.

Apesar de o homem negro africano ter adquirido, com a instauração do modelo europeu de gênero e suas dinâmicas, uma posição de maior poder do que costumava ter em relação à mulher no período pré-colonial, passou também a sofrer de uma subalternidade antes desconhecida: a inferiorização em relação ao homem branco europeu por conta de sua raça e classe social. Desta forma, coube ao homem negro dentro da colônia uma posição social de inferioridade em relação ao homem branco europeu; apesar disso, ainda era reservado ao homem africano o lugar de subordinado ou cúmplice do europeu, condição hierárquica que, ressalta Lugarinho, garantia a esses homens um lugar de certo privilégio social quando comparado ao status social da mulher na época.

\begin{abstract}
O homem negro africano, de maneira geral, passou a experimentar uma dupla condição, antagônica em seus polos, se por um lado passava a exercer um protagonismo social que a sua tradição original não previa, por outro, era instalado numa posição profundamente subalterna, dada por sua origem étnica, racial e geográfica. Nas sociedades crioulas cabiam-lhe as posições subalternas, cumplices ou marginais àqueles que efetivamente exerciam o poder na colônia (os homens brancos europeus), além disso, a hierarquia das masculinidades se confundia com as hierarquias raciais e étnicas, mas concedia ao homem mestiço uns poucos privilégios. (LUGARINHO, Mário César. Paradigmas Confrontados: Algumas Masculinidades nas Literaturas Africanas de Língua Portuguesa. 2017, p.143)
\end{abstract}

As masculinidades ocidentais serviram, como observa Lugarinho, de "paradigma absoluto da masculinidade na história colonial" (LUGARINHO, 2017), visto que foi a partir da identidade do homem branco, independentemente de sua classe ou função social, que as funções e a importância de outros membros da sociedade colonial foram ranqueadas. Assim, enquanto o homem branco ocupava a função de maior importância na comunidade, cabia aos outros indivíduos se adaptar e formular suas identidades a partir do modelo representado pelo colonizador branco ocidental, ou seja, homens, mulheres e crianças, a depender de recortes de raça ou classe social, "eram contabilizados na hierarquia social colonial de maneira que, quanto mais afastados do paradigma, mais subalternamente estavam localizadas" (LUGARINHO, 2017, p.143). Por conta deste arranjo social, Lugarinho afirma que a prática colonial da época perpetuava características associadas ao feudalismo, em 
que havia um sistema de privilégio direcionado ao homem branco e que se distribuía desigualmente a outros membros da sociedade de acordo com o grau de distância do padrão vigente concretizado no homem branco.

Assim, é possível concluir, partindo do que é pontuado por Lugarinho e por Vieira de Jesus acerca da reconfiguração das dinâmicas de gênero a partir do modelo ocidental de gênero, que a colonização influenciou de forma contundente não apenas no modo com que o homem e a mulher eram percebidos socialmente, mas também como essas duas categorias se correlacionavam e dependiam do que Lugarinho chama de "paradigma absoluto da masculinidade na história colonial". Essa reconfiguração do que era entendido como feminino e como masculino no continente, bem como a forma com que essas categoria passaram a se relacionar, influenciou (e ainda influencia) profundamente nos arranjos sociais do país e perpetuou o estereótipo de superioridade do homem branco e europeu em relação a qualquer outro indivíduo inserido tanto no contexto colonial quanto no pós-colonial, culminando na hierarquização social de indivíduos a partir de seu sexo biológico, bem como num sentimento de inferiorização do colonizado em relação às outras culturas. Tais sentimentos, conforme observado anteriormente, reverberam ainda hoje na produção literária do continente africano, bem representada pela escritora nigeriana contemporânea, Chimamanda Ngozi Adichie, principalmente em seu romance de estreia, Hibisco Roxo (2003). 


\section{CAPÍTULO 2}

\section{HIBISCO ROXO: RELAÇÕES DE GÊNERO NA NIGÉRIA PÓS COLONIAL}

\subsection{Pós-Colonialismo em Hibisco Roxo}

Hibisco Roxo, primeiro romance da escritora nigeriana Chimamanda Ngozi Adichie, retrata de forma contundente os impactos da ação do colonizador europeu na Nigéria pós-independência. Ambientado entre os anos 70 e 80, o romance retrata uma Nigéria recém emancipada e profundamente marcada pela instabilidade política e pelos conflitos internos advindos da necessidade pós independência de estabelecer um governo destacado da metrópole. No centro de tamanha instabilidade social e política, está a família de Kambili Achike, a jovem narradora do romance. Na narrativa, o lar de Kambili funciona como microcosmos da sociedade em que está inserido, aonde a presença tirânica de Eugene (pai de Kambili), bem como a forma com que este nega os valores da cultura africana e supervaloriza elementos historicamente herdados da metrópole inglesa, contribuem na construção de um ambiente cerceador e hostil que serve como parâmetro de análise, também, a partir da relação entre Eugene e o resto de sua família (a mãe, Beatrice, e o irmão, Jaja), da forma com que o colonizador europeu erradicou valores culturais da Nigéria, substituindo-os por valores que considerava mais corretos: os seus próprios.

Quando se fala de pós colonialização no contexto do romance de Adichie, é imprescindível que se faça a análise de Eugene, personagem que representa um amálgama de todos os valores ocidentais herdados através da colonização. Eugene é o personagem que melhor reflete na narrativa os efeitos do que Mirian do Nascimento Batista (2014) chama de "a tríade religião-raça-língua", que são três elementos indissociáveis através dos quais pode ser percebida a forma com que a cultura do colonizador foi imposta. É evidente na narrativa de Adichie que o personagem de Eugene, por conta de seu passado e da relação que teve com o homem europeu no período da colonização, sofre um processo de embranquecimento social e de distanciamento da cultura de seu país natal.

Durante a infância, Eugene e sua irmã, Ifeoma, moravam com o pai em uma aldeia de sua tribo igbo. Com a chegada dos missionários à aldeia, as crianças foram convertidas à religião católica e reeducadas formalmente pelos líderes 
religiosos. Eugene, a partir disto, teve acesso ao sistema educacional superior britânico, sendo enviado à Inglaterra para completar os estudos iniciados na colônia, encontrando, como consequência disso, uma grande oportunidade de ascensão social, tornando-se um grande empresário, dono do maior jornal local e, por conseguinte, um dos homens mais ricos de sua região e recebendo o título de omelora, "Aquele Que Faz pela Comunidade” (ADICHIE, 2011. p.63) .

Por conta da educação que, por ser fornecida por missionários, também tinha forte caráter religioso, Eugene tornou-se, também, membro ativo e importante de sua igreja, bem como um cristão fiel, que ia à missa com frequência, sentava-se sempre no banco da frente e era o primeiro a receber a comunhão, além de ser conhecido por ser a pessoa que mais contribuía com sua paróquia, aonde era um dos membros preferidos do missionário local, padre Benedict. Durante seus sermões, padre Benedict sempre falava do papa, do
meu pai e de Jesus - nessa ordem (...). O padre Benedict falava de
coisas que todos já sabiam, sobre como Papa fizera as maiores
doações ao óbolo de São Pedro e à lgreja St. Vincent de Paul. Ou
sobre como Papa pagara as garrafas de vinho usadas na comunhão,
os novos fornos do convento aonde as irmãs assavam a hóstia e a
nova ala do hospital St. Agnes, onde o padre Benedict dava a
extrema-unção. (ADICHIE, Chimamanda Ngozi. Hibisco Roxo, 2011,
p. 10-11)

É perceptível no personagem, por outro lado, uma forte divergência na relação entre as esferas pública e privada de sua vida. Enquanto, para os membros de sua igreja e de sua comunidade, Eugene é um religioso fervoroso que põe em prática em sua congregação os preceitos cristãos de bondade e caridade, em casa ele pratica atos terríveis de violência física e psicológica contra os membros de sua família, comportamento hipócrita que vai de encontro com os ideais religiosos de amor, perdão e compaixão. Eugene é uma bomba-relógio, que explode sempre que, independente por que motivos, os membros de sua família não agem de acordo com suas exigências milimétricamente calculadas, como é percebido claramente em uma passagem do livro em que Kambili está com cólica e sua mãe permite que ela coma alguns flocos de milho para forrar o estômago antes de tomar um analgésico. Tal situação se dá, no entanto, antes da missa de comunhão, que deve ser assistida em jejum. A quebra da regra do jejum, mesmo que por motivos válidos, desperta a ira de Eugene. 
"- Está comendo dez minutos antes da missa? Dez minutos?

- Ela ficou menstruada e está com cólica... - Explicou Mama

[...] - Será que o demônio pediu a você para fazer o trabalho dele? disse Papa, com as palavras em igbo saindo de sua boca numa torrente. - Será que o demônio armou uma tenda dentro da minha casa? [...]

Papa tirou o cinto devagar. Era um cinto pesado feito de camadas de couro marrom com uma fivela discreta coberta do mesmo material. Ele bateu em Jaja primeiro, no ombro. Mama ergueu as mãos e recebeu um golpe na parte superior do braço, que estava coberta pela manga bufante de lantejoulas da blusa que ela usava para ir à igreja. Larguei a tigela sobre a mesa um segundo antes de 0 cinto me atingir nas costas. [...] Papa pareceu um nômade fulani estalando seu cinto em cima de Mama, de Jaja e de mim, murmurando que o demônio não ia vencer. Não demos mais que dois passos para escapar do cinto de couro que cortava o ar.

Então o cinto parou e Papa olhou para o couro em sua mão. Ele franziu o rosto; suas pálpebras desceram.

- Por que vocês se deixam enredar pelo pecado? - Perguntou Papa. - Por que gostam do pecado?" (ADICHIE, Chimamanda Ngozi. Hibisco Roxo, 2011, p.112)

A partir deste excerto é possível perceber, também, que Eugene acredita que com a violência está fazendo a justiça de seu deus cristão e que, através disso conseguirá perdão para sua família pecadora. Assim, conclui-se que a violência de Eugene apresenta sempre um caráter punitivo e é desencadeada por algo que, para ele, é errado ou pecaminoso. Um outro exemplo claro desta noção do personagem de estar fazendo a justiça de Deus através do derramamento de sangue é a passagem em que, por estar grávida e passando por fortes enjoos, Beatrice pede permissão ao marido para não entrar na casa do Padre Benedict quando vão visitalo após a missa. Eugene apenas olha para a esposa de forma ameaçadora e pergunta se ela tem certeza de que não quer entrar. A mulher, movida pelo medo e pela submissão, entra; o que não a impede, no entanto, de ser espancada a ponto de ir parar no hospital e perder o bebê que levava no ventre. Eugene convida então os filhos a "rezar dezesseis novenas. Pelo perdão de Mama" (ADICHIE. p. 42). Ou seja, o personagem, por interpretar que está defendendo a vontade de Deus e intercedendo pelas ações pecaminosas de sua esposa, nem mesmo considera que esteja cometendo qualquer tipo de pecado.

Pode ser entendido, no entanto, que a forma que Eugene entende religião e violência como fatores intrínsecos é consequência da forma igualmente violenta com que, durante a infância e início da vida adulta, foi evangelizado. O personagem, então, reproduz a violência que sofreu acreditando que este é um método legítimo e cristão e que através dele não está fazendo mal algum. A romantização dos 
missionários que, como ele, praticavam violências físicas e psicológicas, é recorrente no discurso de Eugene, o que, apesar de não justificar suas ações, esclarece a forma com que a normalização da violência se enraizou em seu imaginário:

- Uma vez cometi um pecado contra o meu corpo - contou ele. E o bondoso padre, aquele com o qual morei quando estudava em St.Gregory's, ele entrou e me viu. Pediu que eu fervesse água para o chá. Colocou a água numa tigela e me fez pôr as mãos nela.

Papa estava olhando bem nos meus olhos. Eu não sabia que ele um dia tinha cometido um pecado, que era capaz de fazer isso.

- Nunca mais pequei contra o meu corpo de novo. $O$ bondoso padre fez isso pelo meu bem - explicou. (ADICHIE, Chimamanda Ngozi. Hibisco Roxo, 2011, p.209) ${ }^{6}$

Os grifos no texto evidenciam a forma romantizada com que Eugene interpreta a violência desnecessária do missionário, acreditando que esta é cometida por piedade, o que o leva a endeusar a figura do padre abusivo. Como resultado disto, o personagem parece incorporar a si aspectos deste comportamento tirânico, tratando os filhos da mesma forma. Em paralelo ao comportamento submissivo e romantizado de Eugene para com seu algoz, está a relação que Kambili mantém com o pai, que, da mesma forma, tem como arcabouços o endeusamento e a idealização da figura que representa autoridade. Este aspecto da religião no continente é abordado também por Mirian do Nascimento Batista em Hibisco Roxo e o "estereótipo" africano: uma outra história do imperialismo (2014), em que a autora afirma que o uso da religião como arma do colonizador se dá por esta representar algo sagrado, sendo assim uma desculpa para exigir dos fiéis que se faça sacrifícios em nome de algo eterno e promovendo, ainda, mais um sistema de hierarquização social, aonde o padre, que serve de mediador entre deus e o pecador, é visto como autoridade. Desta forma, a igreja "se torna um espaço de poder em que um indivíduo tem sobre si a autoridade de perdoar pecados ou condenar uma pessoa". (BATISTA, 2014. p. 36).

Um outro aspecto da deturpação da religião católica por parte de Eugene e dos missionários brancos que trazem e perpetuam a religião católica no país se dá pela forma antagônica com que retratam as religiões de matriz africana. Em Hibisco Roxo, é perceptível que missionários brancos, como as freiras britânicas do colégio

${ }^{6}$ Grifo nosso. 
de Kambili ou padre Benedict, que suprime em sua paróquia qualquer rito que remeta às crenças igbo, formam seu conceito do que é cristão a partir de ideais xenofóbicos, como é evidenciado no trecho:

O padre Benedict mudara as coisas na paróquia, insistindo, por exemplo, que o credo e kyrie fossem recitados em latim; igbo não era aceitável. Além disso, devia-se bater palmas o mínimo possível, para que a solenidade da missa não ficasse comprometida. Mas ele permitia que cantássemos músicas de ofertório em igbo; chamava-as de músicas nativas, e quando dizia "nativas" a linha reta de seus lábios pendia nos cantos e formava um $U$ invertido. (ADICHIE, Chimamanda Ngozi. Hibisco Roxo, 2011, p. 10)

É possível concluir, com base nisso, que agentes passivos da colonização têm, então, seu ideário constituído a partir dos princípios segregadores dos missionários católicos europeus, que disseminam a ideia de que tudo que não se enquadra no ideal católico-branco-ocidental é errado. Tal comportamento agressivo em relação aos valores religiosos de sua própria cultura é facilmente observado em Eugene, que, assim como padre Benedict, abomina cantorias e o bater de palmas característicos da vertente católica do povo igbo, e da preferência aos moldes religiosos tradicionalmente europeus (e brancos). Da mesma forma, Eugene abomina o que chama de "paganismo", que é a religião politeísta praticada por seu pai, Papa-Nnukwu.

É a partir da figura de Papa-Nnukwu e de sua relação com Eugene que se pode observar claramente a maneira com que o segundo foi cegado por sua religião. Papa-Nnkwu, que não sofreu a influência ideológica e religiosa dos missionários colonizadores, pratica uma religião politeísta de origem africana, prática esta que é vista com maus olhos por seu filho, que procura, de todas as maneiras possíveis, converter o pai ao catolicismo. Quando falha em fazê-lo, Eugene assume então uma postura radical, banindo o pai de sua vida e da vida de seus filhos.

Papa-Nnukwu contara à umunna que Papa se oferecera para construir uma casa, comprar um carro e contratar um chofer para ele, contanto que ele se convertesse e jogasse fora o chi e o altar de sapê que havia em seu quintal. Papa-Nnukwu rira e respondera que só queria ver seus netos quando pudesse. Ele não ia jogar fora o seu chi; já dissera isso a Papa muitas vezes. (ADICHIE, Chimamanda Ngozi. Hibisco Roxo, 2011, p.69) 
Durante todo o romance é ressaltada a intolerância de Eugene em relação ao pai, desrespeitando a fé de Papa Nnukwu até mesmo após sua morte, quando insiste em Ihe dar a extrema-unção e enterra-lo em uma cerimônia católica sob alegações de que jamais poderia comparecer a um funeral pagão. Eugene teima em ver seu pai como um ser herege e impuro que não merece estar em sua presença cristã, preferindo abandonar sua família a abandonar seus inflexíveis ideais religiosos.

A religiosidade de Papa-Nnukwu, no entanto, é contrastante com a de seu filho. Eugene o evita de todas as forma e apenas o menciona quando condena seu "paganismo" ou quando fala em converte-lo; como é ressaltado por Kambilli, "quando Papa rezava por Papa-Nnukwu, ele pedia apenas que Deus o convertesse e o salvasse das chamas do inferno." (ADICHIE, 2011.p.161). Papa-Nnukwu, em contraste, reza por seu filho pedindo por seu bem e pelo bem de seus netos, fato que pode ser confirmado através da oração que Kambili ouve seu avô fazer: "Chineke! Abençoe meu filho Eugene. Que o sol de sua prosperidade continue a brilhar." (ADICHIE, 2011.p.179). É claro, a partir da observação destes dois excertos, que a vivência da religião é muito diferente para os dois. Enquanto para Eugene, conforme demonstrado anteriormente, esta apresenta um caráter violento e mecânico, adquirindo contornos quase que de uma obrigação, para Papa-Nnukwu o exercício da fé parece se dar de forma natural, confortável e sem pressão alguma.

\footnotetext{
- Chineke! Abençoe os filhos dos meus filhos. Deixe que seus olhos o acompanhem para longe do mal e perto do bem. Papa Nnukwu sorriu ao falar. [...] Ele ainda sorria quando me virei silenciosamente e voltei para o quarto. Eu nunca sorria depois de rezar o rosário em casa. Nenhum de nós sorria. (ADICHIE, Chimamanda Ngozi. Hibisco Roxo, 2011, p. 179-180)
}

Apesar de Papa Nnukwu parecer não nutrir nenhum sentimento negativo em relação ao filho, é percebido, no romance, um forte ressentimento em relação aos missionários católicos e à implementação da religião na Nigéria. São diversos o momentos em que o personagem demonstra não compactuar com valores católicos impostos ao povo nigeriano, como a condenação de religiões de matriz africana, ou o fato de missionários negros africanos, como padre Amadi, serem enviados para missões na Europa. Fica claro no romance que Papa Nnukwu culpa os missionários 
pelas atitudes preconceituosas e segregadoras do filho e por seu relacionamento conturbado:

\begin{abstract}
- Nekenem, olhe só para mim. Meu filho é dono de uma casa onde cabem todos os homens de Abba, mas muitas vezes eu não tenho nada para colocar no prato. Não devia tê-lo deixado ir atrás daqueles missionários. (ADICHIE, Chimamanda Ngozi. Hibisco Roxo, 2011, p. 91-92)
\end{abstract}

Deve ser destacado, no entanto, que muito embora Papa Nnukwu se ressinta dos missionários e da religião católica, ele nunca fala desta de forma pejorativa. Fato que, mais uma vez, o coloca em uma posição de oposição ideológica em relação a Eugene.

Kambili, assim como seu pai e muito provavelmente por conta da influência e da imposição deste para que se pratique a religião de forma correta, amarrada e seguindo ordens, encara a fé mais como um dever do que como algo espiritual, por isso a surpresa da garota ao perceber que o avô sorri quando reza. Assim, a experiência religiosa de Kambili e de toda a sua família é moldada pelo entendimento de religião engessado do pai que, por sua vez, herdou tal percepção dos missionários que o catequizaram. Tal entendimento entra em conflito direto com a forma livre e despretensiosa com que Papa-Nnukwu encara sua fé, despertando na menina sentimentos de espanto e assombro que, ao poucos, se transformam em admiração. O sentimento culmina, por fim, na compreensão de que, diferentemente do que the foi ensinado pelo pai, é concebível e natural que se pratique religiões diferentes da católica, sendo que essas religiões não necessariamente são fatores determinantes do caráter de quem as pratica.

Fica clara no romance uma forte crítica à religião católica; esta crítica, no entanto, não é direcionada à religião em si, mas à forma patriarcal, excludente e xenofóbica com que esta é praticada, em especial, por Eugene. Fica claro no texto de Adichie que a crítica feita através de Eugene busca atingir aqueles que, cegados por uma fé deturpada, cometem atos de violência em nome de seu deus e se esquecem dos princípios-base de amor e caridade da religião católica. Vale ressaltar também que a autora não aborda apenas o viés negativo da prática da referida religião, visto que retrata outros personagens, como a família de lfeoma e o padre Amadi, que, ao contrário do pai de Kambili, praticam uma religião católica que não 
segrega ou marginaliza, mas segue os preceitos básicos da doutrina, que pregam contra a violência e a favor da bondade e do perdão.

O segundo aspecto da tríade de Mirian do Nascimento Batista (2014), através do qual o colonialismo foi imposto no continente africano, é a raça, aspecto que tornou-se profundamente enraizado no continente e que é, por consequência, tema recorrente na literatura pós colonial, em especial em Hibisco Roxo. Como ressalta Batista, o colonizador, apesar de oferecer educação formal na colônia e, como é o caso de Eugene, por vezes até mesmo educação superior no exterior, nunca abre mão de sua auto proclamada superioridade (FALOLA; HEATON, 2008, apud BATISTA, 2014). Para Mirian do Nascimento, essa superioridade, no entanto, não se resume apenas à cor da pele, mas "trata-se de todo um ethos europeu", que é facilmente exemplificado pela preferência de Eugene pelo pai de Beatrice a seu próprio pai.

[a forma que tratava Papa-Nnukwu] Era muito diferente da forma como Papa tratava o meu avô materno até ele morrer cinco anos atrás. Quando chegávamos à Abba todo Natal, Papa passava na casa do Vovô na nossa ikwu nne, ou casa de solteira da nossa mãe, antes mesmo de irmos à nossa propriedade. Vovô tinha a pele muito clara, era quase albino, e diziam que esse fora um dos motivos pelos quais os missionários haviam gostado dele. Insistia em falar inglês, sempre, com um forte sotaque igbo. Sabia latim também, citando muitas vezes artigos do Concílio Vaticano I, e passava a maior parte do tempo em St.Paul's, onde havia sido o primeiro catequista. Insistia para que o chamássemos de Vovô em vez de Papa-Nnukwu ou Nna-Ochie. Papa ainda falava muito dele, os olhos cheios de orgulho, como se Vovô fosse seu pai. Ele abriu os olhos antes da maioria do nosso povo, dizia Papa; foi um dos primeiros a acolherem os missionários. [...] Fazia as coisas do jeito certo, do jeito que os brancos fazem, não como nosso povo faz agora! (ADICHIE, Chimamanda Ngozi. Hibisco Roxo, 2011, p. $75)^{7}$

Fica óbvio no excerto e a partir da análise dos trechos destacados que a preferência de Eugene por Vovô é fruto não de admiração à pessoa em si, mas à forma com que ele reflete valores e costumes da cultura branca que o pai de Kambili tanto reverencia. Mirian do Nascimento Batista (20014) menciona um fato curioso a respeito de Eugene: até mesmo seu nome faz referência à superioridade que o

\footnotetext{
${ }^{7}$ Grifo nosso.
} 
personagem atribui ao homem branco; "Eugene" parece derivar de eugenia", aproximação que, para do Nascimento Batista, parece não ser fruto do acaso, visto que a própria construção do personagem é permeada pelo ideal de que a aglutinação da cultura ocidental representaria uma melhora para a cultura local. (BATISTA, 2014).

No que tange à percepção de raça no romance, o ponto de vista do colonizador também é abordado através da figura de padre Benedict, que sente-se intelectual, religiosa e racialmente superior ao povo nigeriano. A exemplo de sua intolerância, o personagem, como mencionado anteriormente, extingue valores típicos da cultura local em sua paróquia e parece sentir-se incomodado por tudo aquilo que reconhece como "nativo", aversão esta que é clara em momentos como o que o padre, ao tomar a confissão de Kambili, afirma que ela "precisa entender que é errado gostar de rituais pagãos, pois isso é desobedecer ao primeiro mandamento. Rituais pagãos são superstições falsas, e são a porta de entrada do inferno" (ADICHIE, 2011. p.116). Como reflexo disso, Eugene, que parece estar sempre em busca de agradar aqueles que considera superiores, molda seus comportamentos a fim de parecer mais aceitável aos olhos do missionário:

Papa mudou de sotaque quando respondeu, adotando uma pronúncia
britânica, como fazia quando falava com o Padre Benedict. Ele se
mostrou gracioso e ansioso por agradar, como sempre era com os
religiosos. Principalmente os religiosos bancos. (ADICHIE,
Chimamanda Ngozi. Hibisco Roxo, 2011, p. 52)

É evidente no trecho, além da clara submissão de Eugene ao ideal de supremacia branca, a forma com que a língua, terceira parte da tríade de Mirian do Nascimento Batista (2014), é usada, ao mesmo tempo, como ferramenta de colonização e como forma de criar uma relação hierarquizada entre colonizado e colonizador. São diversos os trechos em que Adichie reafirma a preferência de Eugene pelo uso do inglês (que o personagem pronuncia de forma forçada, buscando evidenciar um sotaque britânico que obviamente não lhe é natural), e evitando falar o dialeto local. Já nas primeiras páginas do livro, é explicitado que,

8 Termo criado em 1883 por Francis Galton, que defendia que o controle social poderia melhorar ou enriquecer as qualidades raciais das futuras gerações, seja física ou socialmente. O termo é comumente associado à higienização social do nazismo, que, assim como defendido na teoria de Galton pregava a exterminação de raças consideradas inferiores (como a negra, por exemplo) a fim de que fosse criada uma sociedade geneticamente pura. 
para Eugene, se expressar em inglês é sinônimo de civilidade, pensamento que se evidencia até mesmo na forma com que Eugene percebe seus conterrâneos como dignos ou não, a partir da forma com que se expressam; conforme afirma Kambili, Eugene gostava que "[...]o povo de Abba se esforçasse para falar inglês perto dele. Dizia que mostrava que tinham bom senso." (ADICHIE, 2011).

Através desses comportamentos de submissão ao homem branco, Eugene funciona como uma confirmação do que Mario César Lugarinho teoriza em Paradigmas Confrontados: Algumas Masculinidades nas Literaturas Africanas de Língua Portuguesa (2017), de que a identidade de todos os membros da sociedade colonial e pós colonial é moldada a partir do homem branco, criando um sistema de hierarquização aonde, a partir da distância em que se encontra do ideal branco, masculino e europeu, o indivíduo é percebido socialmente como mais ou menos importante em seu meio. A partir da teoria de Lugarinho, ainda, percebe-se que essa hierarquização produz uma polaridade na forma que o homem negro africano é socializado, sendo ora submisso, ora opressor.

\subsection{Dinâmicas de gênero em Hibisco Roxo}

Quando se fala dos aspectos de masculinidade em Hibisco Roxo, é natural que se mencione, mais uma vez, Eugene, visto que o personagem parece refletir 0 que há de mais essencial no que tange a herança das masculinidades ocidentais na África, que é a soberania do homem em relação à mulher. Conforme mencionado no capítulo anterior, Lugarinho (2017) afirma que a masculinidade do homem negro africano pareceu se construir a partir da identidade do homem branco, que o escritor chama de "paradigma absoluto da masculinidade na história colonial" (LUGARINHO, 2017. p.143), configuração esta que abriu precedentes para a propagação, na África, do mito ocidental do homem viril e violento, comportamento que é evidente em Eugene e na forma como ele se expressa: sempre através da violência. $O$ personagem parece acreditar que seu papel como pai, marido e homem da casa é controlar sua esposa e seus filhos, comportamento que, mais uma vez, exemplifica a fala de Lugarinho (2017) quando este afirma que, dadas as configurações de gênero do continente, o homem negro, apesar de inferior ao branco, ainda é hierarquizado de tal maneira a ser ranqueado em uma posição social superior à da mulher. 
Desta forma, a masculinidade de Eugene é percebida no livro através da violência que o personagem utiliza para manter sua família "sob controle". Apesar da violência ser característica dominante no personagem, outras formas de dominação são evidenciadas, como a pressão para que os filhos e a esposa se comuniquem principalmente em inglês, evitando o dialeto igbo, a imposição da religião, a coerção para que Jaja e Kambili sejam sempre alunos excelentes (sob pena de castigos físicos caso não obtenham sucesso), e a formulação de horários detalhados e restritivos para que os filhos estejam sempre fazendo algo que ele considera produtivo. Desta forma, Eugene cria em sua casa um ambiente profundamente repressor e claustrofóbico, cercando seus familiares de todas as formas possíveis e os obrigando a viver sob a sombra de um pai e marido tirano.

Outra forma de masculinidade evidenciada no livro é percebida em Jaja, filho mais velho de Eugene. Jaja, que desde muito criança vê a mãe e a irmã mais nova, assim como ele, sofrerem as agressões físicas e psicológicas do pai, nutre, ao longo do livro, um forte ressentimento pela figura paterna, bem como uma sensação crescente de culpa por não se impor e interceder por si mesmo, pela mãe e pela irmã. Tais sentimentos parecem se evidenciar e crescer quando Jaja e Kambili viajam para a casa da tia em Nsukka e o garoto conhece, pela primeira vez em sua vida, um lar acolhedor e respeitoso, onde as individualidades dos membros da família são respeitadas e há espaço para a expressão de opiniões e discussões saudáveis, e que, por isso, é profundamente diferente do seu. $\mathrm{O}$ contato com este lugar e a percepção de seu próprio lar como um ambiente repressivo fazem com que Jaja se rebele, questionando pela primeira vez a autoridade e a supremacia do pai.

\footnotetext{
- Ele foi ser julgado - disse Papa, colocando o copo sobre a mesa. Ifeoma não teve juízo, não chamou um padre antes de ele morrer. Quem sabe ele houvesse se convertido antes de morrer.

- Talvez ele não quisesse se converter - disse Jaja.

[...] - O que você disse? Foi isso que aprendeu quando estava morando na mesma casa que um pagão?

- Não - disse Jaja.

Papa olhou primeiro para Jaja, depois para mim, balançando a cabeça lentamente, como se houvéssemos mudado de cor. [...] - Papa, o senhor pode me dar a chave do meu quarto, por favor? - disse Jaja, pousando 0 garfo sobre 0 prato. Estávamos no meio do jantar. Inalei fundo e prendi a respiração. As chaves de nossos quartos sempre haviam ficado com Papa.

- O quê? - perguntou Papa.

- A chave do meu quarto. Queria que o senhor me desse. Makana, gostaria de ter um pouco de privacidade.
} 
As pupilas de Papa dispararam de um lado para o outro dentro do branco de seus olhos. (ADICHIE, Chimamanda Ngozi. Hibisco Roxo, 2011, p. $203-204)$

Os pequenos atos de insubordinação de Jaja, no entanto, crescem, fazendo com que o garoto passe a fazer exigências ao pai, como quando demanda que o pai mande a ele e a irmã a Nsukka antes que sua tia Ifeoma e seus primos Amaka, Obiora e Chima se mudem para os Estados Unidos, comportamento este que o Jaja subordinado e conformado do início da história provavelmente nunca teria.

Com a insubordinação, no entanto, o sentimento de culpa também aumenta. Jaja se sente responsável pela mãe e pela irmã e se ressente profundamente de nunca tê-las defendido da violência de seu pai: "Eu devia ter tomado conta de Mama. Veja como Obiora equilibra todo o peso da família de Tia Ifeoma sobre a cabeça. E eu sou mais velho do que ele. Devia ter tomado conta de Mama. (ADICHIE, 2011. p. 304). Tal sentimento de que deve assumir o papel de "homem da casa" que a sua masculinidade requer e, por conseguinte, incumbir-se de tomar de conta da mãe e da irmã, cresce e atinge níveis estratosféricos, culminando, no fim do romance, em Jaja, por achar que deve se responsabilizar pela mãe, assumir um assassinato que Beatrice havia cometido e ir para a prisão em seu lugar.

Apesar de nobre, a atitude de Jaja evidencia que o personagem está incorporando as atitudes machistas do pai, como a percepção da mulher como um objeto de posse e o sentimento de que é seu dever como homem orientá-la e controla-la. Desta forma, é possível concluir que as masculinidades tóxicas ocidentais herdadas pelo contato com o colonizador branco parecem se configurar de forma hereditária e cíclica, sendo apreendidas de pai para filho e, portanto, tendendo a perpetuar-se infinitamente. Pode-se concluir, além disso, que a masculinidade de Jaja, apesar de menos perniciosa que a do pai, é ainda muito prejudicial às mulheres com as quais convive, pois afeta diretamente na liberdade física e de discurso destas, moldando, como ressaltado anteriormente por Lugarinho (2017), a forma com que a identidade feminina é construída.

Desta forma, no contexto de Hibisco Roxo, as mulheres parecem construir-se ao redor do paradigma masculino, sendo este, no caso de Kambili e Beatrice, Eugene. Assim, as mulheres da família Achike revolvem em torno da figura deste, 
adequando-se aos padrões impostos pelo homem, reinventando-se e podando-se a partir das exigências dele. Quando se analisa as duas personagens e a forma com que a identidade delas é moldada a partir de Eugene, dois aspectos principais devem ser discutidos: o silêncio e a subordinação destas frente à figura do homem. A alienação advinda da repressão representada por Eugene é tamanha que, como ressalta Okuyade (2009), o conservadorismo e as demandas desproporcionais do pai são aceitos pelos filhos e pela esposa sem que haja qualquer tipo de questionamento racional ou dialético.

É ressaltado, diversas vezes ao longo do livro, que o silêncio permeia a vida daqueles que habitam a casa de Eugene. Tal silêncio, como afirma Ogaga Okuyade em Changing Border and Creating Voices: Silence as a Charater in Chimamanda Adichie's Purple Hibiscus, parece ser produto direto da tirania de Eugene:

\begin{abstract}
He runs his home with a zero tolerance in its grossest and most intransigent sense and this in-turn reduces his family to a resonating silence in almost all their endeavors, outside and inside the home. As the narrative develops, one notices varied forms of silence. Kambili, Jaja and their mother speak with their spirit. Sometimes they converse with their eyes. Kambili's mother hardly talks and when she does, it is in mononosyllabes. (OKUYADE, Ogaga. Changing Borders and Creating Voices: Silence as a Character in Chimamana Adichie's Purple Hibiscus, 2009, p.248) ${ }^{9}$
\end{abstract}

Percebe-se, assim, que este silêncio cerca Jaja, Beatrice e Kambili da mesma forma no início do livro, situação que muda conforme o personagem de Jaja é desenvolvido. Assim, muito embora esse silêncio seja comum a todos os que sofrem com a repressão de Eugene, ele é muito mais evidente nas personagens femininas.

Desde o início da narrativa, percebe-se que Kambili, apesar de ser a narradora, possui pouquíssimos momentos de fala no romance. A garota comenta, diversas vezes, que tem o impulso de falar, ou que, em algumas situações, sente que deveria, mas algo a impede de se expressar, fazendo-a preferir manter-se em silêncio. São recorrentes na narrativa momentos em que a narradora relata sintomas físicos que a impedem de se expressar através da fala ou até mesmo de gestos

\footnotetext{
${ }^{9}$ Ele administra sua casa com tolerância zero em seus sentido mais horrível e intransigente, o que reduz sua família a um silêncio ressonante em quase todos os seus aspectos, dentro ou fora de casa. Com o desenvolver da narrativa, percebe-se variadas formas de silêncio. Kambili, Jaja e sua mãe falam com através de seus espíritos. Às vezes, eles conversam com os olhos. A mãe de Kambili raramente fala, e quando ela o faz, é mossilábica. (Tradução livre)
} 
simples e naturais como o de sorrir, sintomas que explicitam a profundidade do terror psicológico sofrido pela garota, que passa a somatizar os danos psicológicos infligidos a ela por seu pai:

Meus primos riram, e Amaka olhou para Jaja e para mim, talvez achando estranho não rirmos também. Eu quis sorrir, mas estávamos passando na frente de casa naquele momento, e a visão dos enormes portões negros e dos muros brancos paralisou meus lábios. (ADICHIE, Chimamanda Ngozi. Hibisco Roxo, 2011, p. 91)

Muito embora, conforme pode ser percebido no trecho acima, esse silenciamento seja comum a todos os personagens que sofrem com a repressão de Eugene, ele é muito mais evidente nas personagens femininas que em Jaja, principalmente após o grande desenvolvimento pelo qual o personagem passa após viajar para Nsukka, aonde desenvolveu maior confiança e habilidade de se comunicar. Kambili, apesar de passar pelo mesmo processo e alcançar os mesmos resultados no fim, o faz de forma muito mais lenta, estabelecendo essa liberdade apenas após a morte do pai. A diferença no ritmo em que os irmãos se desenvolvem é clara, principalmente quando, já no fim do livro, Kambili ainda se mostra, por diversas vezes, muito surpresa com a recém adquirida habilidade de se comunicar do irmão, perguntando-se por diversas vezes como ele consegue se comunicar de forma tão desenvolta tendo sido, um dia, tão retraído quanto ela. O silenciamento e a saída deste, apesar de acontecer em momentos divergentes e afetar os irmãos de forma diferente, tem a mesma origem: a casa da família.

Desde o início da narrativa, Kambili fala de Nsukka e de sua casa em Enugu sempre de forma comparativa, ressaltando como a dinâmica da casa de sua tia é diferente da sua. Kambili narra com admiração a forma com que, na casa de Ifeoma, apesar das condições precárias e da escassez de recursos básicos, as risadas fluem e discussões afloram rapidamente e "o ar era livre para ser respirado à vontade" (ADICHIE, 2011. p.130), dinâmica que vai de encontro com o silêncio sufocante e opressor da casa da protagonista. Desta forma, é possível perceber que Nsukka passou a representar para a personagem um sinônimo de liberdade, sentimento que cresce e representa grande importância na formação desta. É apenas no epílogo do livro, passado algum tempo da morte de seu pai, que Kambili, 
ao revisitar Nsukka, segue os passos do irmão mais velho e se mostra mais livre, permitindo-se, pela primeira vez, rir.

Enquanto voltávamos a Enugu, eu ri alto, mais alto que o canto de Fela. Ri porque as ruas sem asfalto de Nsukka sujam os carros de poeira durante o harmattan e de lama grudenta durante a estação de chuvas. Porque, nas ruas que são asfaltadas, os buracos surgem de repente como presentes surpresa, 0 ar cheira a colinas e história e a luz do sol espalha a areia e a transforma em pó de ouro. Porque Nsukka pode libertar algo no fundo de sua barriga que sobe até a garganta da gente e sai sob a forma de uma canção sobre a liberdade. E sob a forma de riso. (ADICHIE, Chimamanda Ngozi. Hibisco Roxo, 2011, p.313)

O trecho acima mostra, também, a importância de Nsukka na formulação da nova identidade de Kambili, evidenciando que a cidade, assim como sua tia e seus primos, mostraram para Kambili uma realidade alternativa à que a garota estava acostumada, o que a encorajou a assumir uma nova postura diante de situações em frente às quais ela anteriormente se mostraria introspectiva. Tal revolução, no entanto, nunca chega a acontecer com a mãe de Kambili e Jaja. Pelo contrário, Beatrice, que já havia se mostrado ainda mais silenciada e monossilábica que Kambili desde o início do livro, parece, ao fim da narrativa, assumir uma postura ainda mais calada, tornando sua característica principal o silêncio sepulcral. Desta forma, mesmo após a morte de Eugene, o silêncio que a presença deste impunha, mesmo que de forma menos pungente, se mantêm, afetando principalmente Beatrice, e alterando em definitivo o relacionamento desta com o mundo e com seus filhos:

\begin{abstract}
$\mathrm{Na}$ maioria das vezes, ela [Beatrice] só responde assentindo ou balançando a cabeça e eu me pergunto se escutou mesmo. Eu costumava pedir que Sisi conversasse com Mama, porque ela ficava horas sentada na sala de estar com Sisi. Mas Sisi contou que Mama não respondia, que ela só olhava para o nada, em silêncio. [...] Agora, Sisi vai a nossa casa uma vez por semana para dar instruções para a nova governanta, Okon, e perguntar a Mama se ela precisa de alguma coisa. Mama em geral não diz nada, só balança a cabeça e oscila para frente e para trás. (ADICHIE, Chimamanda Ngozi. Hibisco Roxo, 2011, p. 312)
\end{abstract}

Percebe-se, assim, que a masculinidade tóxica de Eugene moldou Beatrice de tal maneira, que, mesmo após se ver liberta da presença sufocante do marido, a mulher não consegue fugir das marcas que o relacionamento tóxico deixou nela. 
No que tange os aspectos da feminilidade e a forma com que eles se configuram a partir da identidade masculina no livro, pode-se traçar um paralelo entre Kambili e sua prima Amaka, bem como entre Beatrice e Ifeoma. Fica claro, desde que a família de Ifeoma aparece pela primeira vez no romance, que os aspectos da feminilidade que permeiam a construção psíquica e identitária de Kambili e de Beatrice não afeta as mulheres desta família da mesma forma, o que leva a conclusão de que o paradigma identitário do homem formulado por Lugarinho (2017), parece ter um alcance reduzido fora do ambiente doméstico, como fica evidenciado pela fala de Ifeoma:

- Você esqueceu que Eugene se ofereceu para me comprar um carro antes até de Ifediora morrer? Mas ele queria que entrássemos para a Ordem de São João. Queria que mandássemos Amaka para um colégio de freira. Queria até que eu parasse de usar maquiagem! Eu quero um carro novo, nwunye $m$, quero voltar a usar meu fogão à gás, quero um freezer novo e quero dinheiro para não precisar desfazer a bainha das calças de Chima sempre que ele cresce. Mas não vou pedir que meu irmão se incline para eu puxar o saco dele e poder ganhar essas coisas. (ADICHIE, Chimamanda Ngozi. Hibisco Roxo, 2011, p. 104) $)^{10}$

Assim, percebe-se que, muito embora Eugene mantenha sua postura dominadora mesmo com Ifeoma e seus filhos, seu comportamento não os afeta da mesma maneira, visto que estes estão distanciados do ambiente em que Eugene exerce sua tirania com maior efeito: sua casa.

Da mesma forma, é possível comparar as mulheres da família Achike com Amaka e Ifeoma no que tange o silêncio e a submissão. Amaka, desde o início, parece ter sido construída de forma oposta à Kambili. Enquanto Kambili é uma adolescente perfeitamente submissa e subalterna, que se cala diante qualquer situação que não lhe pareça confortável, Amaka é livre, cheia de opiniões que não teme expressar e dona de uma voz forte e incisiva que se impõe sempre que necessário.

- Sua fábrica é que faz esse suco, tio Eugene? - Perguntou Amaka, estreitando os olhos para ver melhor o que estava escrito nas garrafas.

10 É evidente no trecho escolhido a forma com que Eugene parece se preocupar mais com domesticar as mulheres da família de Ifeoma do que em impor regras, também, para os homens, o que se confirma através da exigência que ele faz de que Ifeoma pare de usar maquiagem e mande sua filha para um colégio interno, não se preocupando em impor regras e limites para os sobrinhos, o que parece se dever ao fato de estes serem do sexo masculino. 
- Sim - respondeu Papa.

- É um pouco doce demais. Seria mais gostoso se vocês colocassem menos açúcar.

Amaka falou no tom de voz educado e que normalmente se usava para conversar com uma pessoa mais velha. Não consegui perceber se Papa assentiu ou se sua cabeça simplesmente se moveu por causa da mastigação. [...] Eu ficava atônita de ver Amaka fazendo aquilo, abrindo a boca e deixando as palavras jorrar com tanta facilidade. (ADICHIE, Chimamanda Ngozi. Hibisco Roxo, 2011, p. 108)

Além da surpresa que a facilidade de se expressar de Amaka causa em Kambili, conforme evidenciado na passagem acima, desde o seu primeiro contato com Amaka, Kambili também percebe as diferenças marcantes entre as duas, percebendo como a outra, apesar de ter a mesma idade que ela, parece ser bem mais velha, fato que não se dá por conta da aparência, mas por conta da maturidade de Amaka, maturidade esta que ainda falta em Kambili, que é claramente infantilizada e alheia a si e às condições sociais de seu país por conta da forte repressão que sofre por parte do pai.

Amaka se expressa de forma natural, não se preocupando jamais, ao contrário de Kambili, em medir suas palavras ou em formular opiniões que agradem. Buscando sempre expor o que acha, a garota não teme sofrer retaliações e não pensa duas vezes antes de expor opiniões controversas. Enquanto é característico de Amaka um comportamento subversivo e de questionamento de autoridade e das amarras sociais impostas à mulher, Kambili se limita a curvar-se às vontades do pai, chegando ao ponto de nem mesmo pensar em si mesma como indivíduo, ou em seu futuro.

\footnotetext{
- É nesse campo que fazemos nossos bazar - disse tia Ifeoma - E aqui ficam os alojamentos femininos. Esse é o Mary Slessor Hall. Aquele é o Okpora Hall e esse é o Bello Hall, o dormitório mais famoso, onde Amaka jura que vai morar quando entrar na faculdade e fundar seus movimentos ativistas.

- Quem sabe vocês duas não ficam no mesmo dormitório, Kambili?

Assenti automaticamente, embora tia Ifeoma não pudesse me enxergar. Eu nunca me perguntara em que universidade nem em que me formaria. Quando chegasse a hora, Papa decidiria. (ADICHIE, Chimamanda Ngozi. Hibisco Roxo, 2011, p. 140) ${ }^{11}$
}

O trecho ressaltado mostra como Kambili se submete ao pai de tal forma que nem mesmo pensa em si como alguém que pode ter vontades ou tomar

11 Grifo nosso. 
decisões por si só. Kambili, por ser tratada como objeto, se comporta como tal, comportamento que difere do da prima em todos os sentidos. Pode-se concluir então, com base em uma análise contrastiva de ambas as personagens, que o comportamento desenvolto e livre de amarras de Amaka parece se dar por conta do ambiente saudável em que foi criada, aonde nunca foi repreendida se não para o seu próprio bem, e aonde sua opinião nunca foi tolhida ou completamente silenciada, como se deu com Kambili. O comportamento destemido e revolucionário de Amaka parece ser fruto da influência positiva da mãe, que com comportamentos como $o$ de não se submeter às exigências do irmão, mostra-se uma mulher independente e bem resolvida e que, provavelmente, nunca sofreu em seu lar a mesma repressão sofrida por Kambili e Beatrice.

Naquele instante, percebi que era isso que tia Ifeoma fazia com meus primos, obrigando-os a ir cada vez mais alto, graças ao que esperava deles. Ela fazia isso o tempo todo, acreditando que eles iam conseguir saltar. E eles saltavam. (ADICHIE, Chimamanda Ngozi. Hibisco Roxo, 2011, p. 238)

Deve-se ressaltar, ainda, que o desenvolvimento psicológico e social saudável destas mulheres provavelmente foi, também, fruto de influências positivas do marido de Ifeoma, que apesar de pouco mencionado no livro, é sempre lembrado como modelo positivo pela esposa, fato que nos faz deduzir uma possível divergência de ideias e comportamentos entre ele e Eugene. Diferenças estas que, partindo do pressuposto de Lugarinho de que o comportamento do homem serve de paradigma para a formulação da identidade feminina e da afirmação anterior em relação ao alcance da influência da masculinidade ser maior no ambiente doméstico, parecem ter afetado diretamente as personalidades de Amaka e Ifeoma. ${ }^{12}$

Da mesma forma que Amaka e Kambili podem ser analisadas como construções de feminilidade opostas dentro de Hibisco Roxo, quando se fala dos aspectos da construção de Ifeoma, é natural contrastá-la com Beatrice, personagem que parece servir como antítese da mulher expansiva, assertiva e comunicativa que ela é. Beatrice que, conforme mencionado anteriormente, é uma mulher silenciada, submissa e, a princípio, aparentemente conformada com a situação precária em que

\footnotetext{
12 Não se deve, no entanto, assumir que a feminilidade positiva das personagens se deve única e exclusivamente à relação que tiveram com o homem, mas também aos estudos a que tiveram acesso e à própria personalidade e socialização de cada uma.
} 
vive, diverge de Ifeoma não só em sua condição subalterna, mas também na forma com que constrói opiniões à respeito de sua própria casa, das condições da mulher na sociedade em que está inserida e com relação ao casamento.

- A umunna sempre diz coisas que magoam - disse Mama. - Nossa própria umunna não disse a Eugene que ele devia escolher outra esposa, pois um homem de sua estatura não pode ter só dois filhos? Se pessoas como você não tivessem ficado do meu lado naquela época...

- Pare, pare com essa gratidão. Se Eugene tivesse feito isso, a perda teria sido dele, não sua.

- Isso é o que você diz. Uma mulher com filhos e sem marido é o quê?

$-\mathrm{Eu}$.

Mama balançou a cabeça.

- Lá vem você de novo, Ifeoma. Você sabe o que eu quis dizer. Como uma mulher pode viver assim? - Perguntou Mama. Seus olhos estavam arregalados, ocupando mais espaço em seu rosto.

- Nwunye $m$, às vezes a vida começa quando o casamento acaba.

$[\ldots]$

- Conversa de Universidade de novo. Um marido coroa a vida de uma mulher, Ifeoma. [...] (ADICHIE, Chimamanda Ngozi. Hibisco Roxo, 2011, p. 84) $)^{13} 14$

Os trechos destacados revelam que Beatrice, apesar das condições em que vive e de seu casamento com um homem tirânico, agressivo e repressor, parece ainda assim romantizar o enlace matrimonial, acreditando que este é uma benção na vida de toda mulher. Pensamento que provavelmente se dá, mais uma vez, por conta das dinâmicas de gênero ocidentais e da consequente reforma do papel social do homem e da mulher a partir deste, papeis estes que, conforme mencionado anteriormente, reduzem a mulher a uma figura que deve estar sempre recolhida ao ambiente doméstico, certificando-se sempre de agradar e servir o marido, sendo estas as maiores fontes de alegria que uma mulher pode ter na vida.

As profundas diferenças nas vidas destas mulheres, no entanto, não servem para distanciá-las, mas, pelo contrário, as aproximam. O relacionamento de Kambili e Amaka, que a princípio era conturbado porque Amaka acreditava que sua prima, por ser rica e tão reservada era esnobe, mudou completamente quando tomou consciência das dificuldades enfrentadas por Kambili no ambiente em que vivia. Tal mudança, exemplo de sororidade e da importância da união e resistência feminina

\footnotetext{
13 Grifo nosso.

${ }^{14}$ A passagem mostra como o efeito da colonização influenciou, no personagem de Eugene, a quebra das masculinidades típicas do continente africano, como a poligamia, e contribuiu com a construção de uma masculinidade ocidental, com valores opostos, como a monogamia.
} 
frente a situações delicadas como a de Kambili e Beatrice, influenciou bastante no desenvolvimento de Kambili como mulher, bem como contribuiu com o sentimento de pertencimento, que, por fim, culminou na grande revolução de Kambili como personagem.

\begin{abstract}
Eu sorri. Jamais havia sentido a cumplicidade que eu sentia ali, sentada ao lado de Amaka, ouvindo suas fitas de Fela e de Onyekano minúsculo som, no qual ela colocara pilhas novas. Jamais havia sentido o silêncio confortável que compartilhamos enquanto limpávamos o arroz com cuidado, porque os grãos eram pequenos e às vezes pareciam com pedrinhas transparentes. Até 0 ar parecia parado, acordando bem devagar depois da chuva. As nuvens começavam a se dissipar, como tufos de algodão doce soltando-se relutantemente uns dos outros. (ADICHIE, Chimamanda Ngozi. Hibisco Roxo, 2011, p. 261)
\end{abstract}

Beatrice, de forma semelhante, embora menos decisiva, é tocada por Ifeoma, que quando percebe a situação de perigo em que a cunhada e os sobrinhos estão, não hesita em aconselhá-la a se separar de Eugene antes que as coisas tomem rumos ainda mais devastadores. Beatrice que, conforme mencionado anteriormente, considera seu casamento uma bênção e é completamente submissa ao marido abusivo, parece, a partir desse momento, passar por um lento processo de libertação da figura opressora de Eugene. A personagem passa a, aos poucos, abandonar velhos costumes que adquirira com os anos de submissão, como o de não se impor e aceitar tudo que o marido faz em silêncio e, de forma sutil, passa a se desvencilhar das velhas amarras que o marido impusera a ela, abrindo caminho para a liberdade que viria a alcançar no fim do livro.

[...] Quando Mama pediu que Sisi varresse o chão da sala de estar, para ter certeza de que nenhum fragmento perigoso das estatuetas ainda estivesse oculto em algum lugar, ela não abaixou a voz. Não escondeu o minúsculo sorriso que formava covinhas nos cantos de sua boca. Não levou a comida até o quarto de Jaja escondida num pedaço de pano para que parecesse que estava apenas carregando a roupa limpa dele. Levou a comida numa bandeja branca e num prato de mesma cor. (ADICHIE, Chimamanda Ngozi. Hibisco Roxo, 2011, p. 273)

A partir de então, Beatrice passa a adotar, de forma bastante lenta e sutil, comportamentos cada vez mais destoantes da postura submissa que tinha no início do romance, chegando até a, seguindo o conselho de lfeoma, deixar a casa do marido e partir para Nsukka. A fuga, no entanto, não parece ser suficiente; mesmo à 
distância, a sombra opressiva de Eugene paira sobre Beatrice e seus filhos, e, desta forma, percebe-se que a liberdade de nenhum deles será completa enquanto Eugene estiver vivo. Tendo conhecimento deste fato e como recurso final, portanto, Beatrice envenena o marido aos poucos, alcançando, com a morte deste, se não uma vida mais feliz, uma vida livre de violência e do silêncio opressivo que pairava sobre sua cabeça, alcançando, ao invés disso, o que Kambili chama de um silêncio diferente.

Apesar de se mostrar resistente de início, Beatrice segue os conselhos de Ifeoma, quebrando o estereótipo do que seria esperado dela como mulher e esposa submissa em uma sociedade que segue padrões de gênero predominantemente ocidentais que pregam a inferioridade e subserviência da mulher. Beatrice, desta forma, borra os limites do padrão estabelecido de feminilidades e se desloca para um modelo mais flexível de gênero, onde, de forma semelhante ao período précolonial na Nigéria, a mulher, apesar de ainda estar em condição de inferioridade social em relação ao homem, encontra-se numa posição de maior independência e mobilidade social, tendo então, apesar de sua posição inferior, condições de alcançar um status social de maior valor. Fica explicito, além disso, no romance de Adichie, a importância da resistência feminina e da sororidade na vida de mulheres que vivem à margem, como Beatrice e Kambili. 


\section{CONSIDERAÇÕES FINAIS}

Hibisco Roxo, romance de Chimamanda Ngozi Adichie publicado em 2003, conta a história da família Achike em paralelo aos conflitos internos vividos na Nigéria no período pós-colonial, abordando, também, a influência do colonialismo nas relações de gênero no país. A casa da família, que serve de microcosmos da sociedade em que está inserida, serve de palco para cenas de violências física e psicológica praticadas pelo patriarca da família, Eugene Achike. Ao longo do romance, são explorados os relacionamentos entre Eugene e seus familiares, bem como destes entre si e com o mundo. Fica evidente, no romance, a forma com que Eugene, pautado pelo ideal masculino do colonizador branco, reformula sua identidade e a partir disso molda o comportamento de seus filhos, Kambili e Jaja, e de sua esposa Beatrice.

Este trabalho teve como objetivo, a partir do estudo da afirmação de Lugarinho (2017) a respeito da posição do homem branco como paradigma absoluto de masculinidade nas sociedades colonial e pós colonial na Nigéria, analisar as formas de masculinidade presentes em Hibisco Roxo e de que maneiras estas afetam na construção das identidades feminina e masculina no livro. A fim de contextualizar a obra e identificar a origem destas masculinidades e feminilidades, foram levadas em conta também as influências do colonialismo e do póscolonialismo na Nigéria nas formulações destas feminilidade e masculinidades e, portanto, nas relações de gênero. Da mesma forma, foi analisado o impacto do PósColonialismo no personagem Eugene e na maneira com que ele passou a enxergar sua própria cultura após o contato com o colonizador.

Foi percebida, a partir disso, a forma com que a masculinidade do homem branco imposta no período colonial influenciou na construção das identidades femininas e masculinas no país e de que maneira, ao longo do tempo, estas se fizeram cíclicas e renováveis, modificando-se, porém mantendo-se presentes a cada geração. Foi observada, ainda, que apesar da subalternidade da mulher nigeriana frente a essa nova configuração de gêneros, é possível para a mulher borrar os padrões vigentes (muito embora, como retratado no romance e observado neste trabalho, isso se dá de forma lenta e gradual e nunca completa, visto que, conforme 
percebido no romance, as masculinidades ainda afetam essas mulheres de alguma maneira, mesmo que de forma menos contundente). O romance de Adichie mostra o impacto que a sororidade pode ter na vida destas mulheres, possibilitando a resistência e consequente quebra de padrões. 


\section{REFERÊNCIAS}

ADICHIE, Chimamanda Ngozi. Hibisco Roxo. São Paulo: Companhia das Letras, 2011.

BEAUVOIR, Simone de. O Segundo Sexo vol. 2. Rio de Janeiro: Nova Fronteira, 1980.

ASHCROFT, Bill et al.The Empire Writes Back. London: New Accents, 2002.

ADICHIE, Chimamanda Ngozi. The Danger of a Single Story. Palestra promovida pelo Technology, Entertainment, Design (TED), jul. 2009. vídeo (19 min.). Disponível em:<http://www.ted.com/talks/lang/eng/chimamanda_adichie_the_danger_of_a_singl e_story.html> acessado em 23/11/2017.

BONNICI, Thomas. Pós-colonialismo e Representação Feminina na Literatura Pós-Colonial em Inglês. Maringá, v. 28, n.1, p.13-25, 2006.

OKUYADE, Ogaga. Changing Borders and Creating Voices: Silence as

Character in Chimamanda Adichie's Purple Hibiscus. Nigéria: The Journal of Pan African Studies, vol.2, no.9, Março 2009.

RESENDE, Roberta Mara. Gênero e Nação na Ficção de Chimamanda Ngozi Adichie.UFSJ: Agosto de 2013.

AZUIKE, Maureen. Women's Struggles and Independence in Adichie's Purple Hibiscus and Half of a Yellow Sun. An International Multi-Disciplinary Journal, Ethiopia Vol. 3 (4), July, 2009.

JESUS, Diego Santos Vieira de. Bravos Novos Mundos: Uma Leitura PósColonialista Sobre Masculinidades Ocidentais. Estudos Feministas, Florianópolis, 19(1): 312, janeiro-abril/2011.

LUGARINHO, Mário César. Paradigmas Confrontados: Algumas Masculinidades nas Literaturas Africanas em Língua Portuguesa. UFRJ: Metamorfoses, 2017.

BATISTA, Mirian do Nascimento. Hibisco Roxo e o "Estereótipo" Africano: Uma Outra História do Imperialismo. UFRGS: 2014. 